\title{
The Importance of Human Inequalities and Health Care Quality in Life Expectancy of Countries
}

\author{
Orhan Kandemir ${ }^{1}$ \\ ${ }^{1}$ Department of Economics, Kastamonu University, Kastamonu, Turkey \\ Correspondence: Orhan Kandemir, Department of Economics, Faculty of Economics and Administrative Sciences, \\ Kastamonu University, Kastamonu, Turkey.
}

Received: August 25, 2016

Accepted: September 10, 2016

Online Published: October 10, 2016

doi:10.5430/ijfr.v7n5p140

URL: http://dx.doi.org/10.5430/ijfr.v7n5p140

\begin{abstract}
In Human Development Reports published by The United Nations Development Programme (UNDP), the development in the health dimension is measured by life expectancy at birth. In the context of this study, factors that affect life expectancy in 130 countries were analyzed with the help of established multiple regression model. The independent variables of the model, except the proportion of health expenditure in GDP, human inequality, gross national income per capita and satisfaction with health care quality are found to be statistically significant. This situation indicates that the quality of health services in the country in terms of life expectancy is more important than the amount of health care expenditures. The most influential variables on life expectancy at birth were found in order as; human inequality, gross national income per capita and satisfaction with health care quality.
\end{abstract}

Keywords: human development, life expectancy, health care quality, human inequalities, health expenditures

\section{Introduction}

Within the aim of ensuring the sustainable development of society, there are four important dimensions and these are economic development, which includes the elimination of extreme poverty, social inclusion, environmental sustainability and good governance. Health as a human right is critical to achieve these four objectives (SDSN (Note 1), 2014:8). Therefore, it is seen that the developed countries especially give attention to the health services. Successful health services will increase the human capital stock of the relevant country (Boyacığlu \& Taşkın, 2012:18). The country that has increasing human capital stock will enter into much faster development process.

At present, the heath dimension in human development index, which is taken as a measure of development, is measured by life expectancy at birth (UNDP, 2014a). As the life expectancy is a factor that affects the development, what can be the determinants of this period have been an important area of research. In this context, the main purpose of the study is to explain the duration of life with new markers such as human inequalities and health care quality in addition to the health expenditures and income variables commonly used in literature.

\section{Lierature Review}

General thought is that there is a relationship between low income (and its result as poverty) and poor health conditions (Benzeval \& Judge, 2001). The low level of income is closely connected with the lack of individual capacity. Because, low-income causes starvation and malnutrition as well as low literacy rate and lack of physical health. On the other hand, better education and health provide higher income (Sen, 2004:35). Therefore, there is a negative relationship between the level of income and the rate of mortality (Palme \& Sandgren, 2008). Even, the relationship between the risk of death and the level of income is quite strong (Jusot, 2006; McDonough et al., 1997).

One of the variables used in the literature to explain the life expectancy at birth is heath expenditures. Studies in this area, a significant and positive relationship between heath expenditures and health consequences such as life expectancy of individuals in a country has been found in general (Kennelly et al., 2003; Jaba et al., 2014).

In addition to income level, distribution of the income in fair is a factor that affects the health dimension of development and therefore the life expectancy. In the studies in this area, it has generally been found that unfair income distribution has a negative effect on the health of community. For example, according to Marmot and Smith (1989), achieved economic successes have an effect on rapid healing in life expectancy in Japan. Not only the wealth in the country but also the reduction of income differences between rich and poor, which accompanied this wealth, had 
positive effects on health. Rodgers (2002), added income and its distribution as an independent variable to explain the life expectancy at birth in countries in the model and found out these two variables highly significant in the results of the analysis. Similarly Tacke and Waldmann (2013), found a positive and significant relationship between infant mortality and income inequality. In another study to support this idea De Vogli et al. (2005), found out a negative correlation between the life expectancy at birth and income inequality.

Although Gini coefficient is used to measure inequality of income in the literature to explain the life expectancy as (Mayrhofer \& Schmitz, 2014; De Vogli et al., 2005; Rodgers, 2002) did, in our study as a measure of social inequalities, the coefficient of human inequality in the UNDP's Human Development Report was used. Because, this coefficient measures not only at the level of income like Gini coefficient, but also measures inequalities that arise in other determinants of human development in health and education. The coefficient of human inequality in UNDP (2014a; 2014b) reports is calculated by taking unweighted arithmetic average of the inequality in income, education and health.

The variable of satisfaction with health care quality that is not commonly used in the literature has been added as the fourth and the last variable of the model to explain the life expectancy. The reason why we used this variable is as OECD (2011:16) expresses that the health status of the community is also affected by social, economic and physical environment of the people, individual lifestyle, behavioral factors and besides good performance of the health care system. The most important dimension in determining the performance of health care systems is accessing to these services and their quality.

The data of satisfaction with health care quality in countries in UNDP reports are determined through a survey in which whether the people of the country are satisfied with accessible current quality health care (UNDP, 2014c:223).

\section{Methodology and Data}

The life expectancy at birth that is a dependent variable in the study has been estimated with a multiple linear regression model, which has independent variables per capita income, human inequalities, satisfaction of heath care quality and health expenditures rates in GDP. The established model is as follows;

$$
L E A B=B_{0}+B_{1} I N C O M E+B_{2} \text { INEQUALITIES }+B_{3} \text { HEALTHCAREQUALITY }+B_{4} \text { HEALTHEXPENDITURE }+\varepsilon i
$$

$\angle E A B$ : Life expectancy at birth of the countries (2013)

INCOME: The ratio of the gross national income per capita of the countries to the world average (2013) (Note 2)

INEQUALITIES: Coefficient of human inequality of the countries (2013)

HEALTHCAREQUALITY: Satisfaction with health care quality in countries (\%) (2008-2012)

HEALTHEXPENDITURE: Total health expenditure (as \% of GDP) (2011)

$\varepsilon i$ : It represents the term "error".

The data used in the model were taken from UNDP's 2014 Human Development Report Statistics (UNDP, 2014d). In the analysis, the data that belong to 130 countries (look at annex table 2) and related to variables in the model were used and the other countries, which don't have all variables in the model, were left out of the analysis.

\section{Results}

Established models with multiple connections can lead to incorrect evaluations. Whether the established models have multiple linear connection or not can be controlled by looking at VIF and tolerance values (Gujarati, 2006; Albayrak, 2005). In this context, when VIF and tolerance values in the table are examined, it can be seen that VIF values of all variables are smaller than 10 , therefore, there is no multi-connection problem.

As seen in the table, the Durbin-Watson statistic in the model provides to test whether there is an auto-correlation or not and if it is around 1.5 to 2.5, it indicates that there is no auto-correction (Kalayc1, 2009: 267). If the statistic of Durbin-Watson is 1.685 , it indicates that there is no auto-correlation. 
Table 1. Multiple regression results

\begin{tabular}{|c|c|c|c|c|c|}
\hline \multicolumn{6}{|c|}{$\begin{aligned} \text { LEAB }= & \mathrm{B}_{0}+B_{1} \text { INCOME }+B_{2} \text { INEQUALITIES + } B_{3} \text { HEALTHCAREQUALITY + } \\
& B_{4} \text { HEALTHEXPENDITURE }+\varepsilon i\end{aligned}$} \\
\hline \multirow[t]{2}{*}{ Variables } & $\begin{array}{l}\text { Unstandardized } \\
\text { Coefficients }\end{array}$ & $\begin{array}{c}\text { Standardized } \\
\text { Coefficients }\end{array}$ & Significant & Tolerans & VIF \\
\hline & B & Beta & & & \\
\hline Constant & 75.753 & & 0.000 & & \\
\hline INCOME & 1.704 & 0.188 & 0.02 & 0.342 & 2.922 \\
\hline INEQUALITIES & -0.536 & -0.609 & 0.000 & 0.442 & 2.264 \\
\hline HEALTHCAREQUALITY & 0.079 & 0.162 & 0.007 & 0.626 & 1.598 \\
\hline HEALTHEXPENDITURE & -0.087 & -0.027 & 0.596 & 0.840 & 1.190 \\
\hline R Square & 0.727 & & & & \\
\hline Adjusted R Square & 0.718 & & & & \\
\hline Anova-Sig. & 0.000 & Durbin-Wa & on: 1.685 & & \\
\hline
\end{tabular}

In multivariate regression analysis, the R-squared value is a measurement of how much the change in dependent variables is explained by the change in independent variables in the model (Altunışık et al., 2007:211). When the results of the analysis are examined, it is seen that independent variables explain nearly 73 percent of the change in dependent variables.

In the model, all the variables except health expenditures share of GDP and the model at 5\% level are statistically significant. While there is a positive relationship between life expectancy at birth and either per capita gross national income or the satisfaction level of health care quality, there is a negative relationship between human inequalities and life expectancy at birth. Actually, this result is an expected state.

Standardized coefficients in the model shows the order of importance of the independent variables (Kalayc1, 2009:269). Therefore, the most influential variable on the dependent variable is as follow; Human inequalities $(\beta: 0.609)$ and per capita gross national income $(\beta: 0.188)$ and satisfaction with health care quality $(\beta: 0.162)$.

\section{Conclusion}

Multiple regression model was established to evaluate the elements that affect the life expectancy at birth, which is one of the most important determinants of human development. The feature of our study is adding two new variables as the satisfaction with health care quality and coefficient of human inequality besides commonly used variables as income and health expenditures in empirical studies related to the subject.

In the model established in the study, all the variables except health expenditures share of GDP were found to be statistically significant and independent variables explains approximately 73 per cent of dependent variable which is a life expectancy at birth. While the gross national income per capita and satisfaction from the health care quality in the countries increase, the life expectancy at birth gets longer, on the other hand, it also decreases if human inequalities increase.

As a result, to extend the average lifespan, it is not only enough to income growth, more importantly; to reduce the inequalities that arise in all areas of society. In addition to this, countries shouldn't only make an effort to increase the amount of money spent in the field of healthcare, but also they should use these expenditures efficiently and should work to improve the quality of health services.

\section{References}

Albayrak, A.S. (2005). Çoklu Doğrusal Bağlantı Halinde En küçük Kareler Tekniğinin Alternatifi Yanlı Tahmin Teknikleri ve Bir Uygulama. ZKÜ Sosyal Bilimler Dergisi, Cilt 1, Say1 1, 105-126. 
Altunışık, R., Coşkun, R., Bayraktaroğlu S., \& Yıldırım E. (2007). Sosyal Bilimlerde Araştırma Yöntemleri: SPSS Uygulamalı. Beşinci Baskı, Sakarya Yayıncılık, Sakarya.

Benzeval, M., \& Judge, K. (2001). Income and health: the time dimension. Social Science \& Medicine, 52(9), 13711390. http://dx.doi.org/10.1016/S0277-9536(00)00244-6

Boyacıoğlu, E.Z., \& Taşkın, Ö. (2012). Sürdürülebilir Kalkınmada Sağlık Ekonomisi ve Edirne İlinin Sağlık Sektörü Açısından Analizi. Ekonomi Bilimleri Dergisi, Cilt 4, No 2.

De Vogli, R., Mistry R., Gnesotto, R., \& Cornia, G.A. (2005). Has the relation between income inequality and life expectancy disappeared? Evidence from Italy and top industrialised countries. $J$ Epidemiol Community Health, 59(2), 158-162. http://dx.doi.org/10.1136/jech.2004.020651

Gujarati, D. N. (2006). Temel Ekonometri, 4. Baskı, (Çevirenler: Ümit Şenesen ve Gülay Günlük Şenesen), Literatür Yayınc1lı, İstanbul.

Jaba, E., Balan, C.B., \& Robu, I.B. (2014). The relationship between life expectancy at birth and health expenditures estimated by a cross-country and time-series analysis. Procedia Economics and Finance, 15(2014), 108-114. http://dx.doi.org/10.1016/S2212-5671(14)00454-7

Jusot, F. (2006). The Shape of the Relationship between Mortality and Income in France. Annals of Economics and Statistics, (83-84), 89-122. http://dx.doi.org/10.2307/20079164

Kalaycı, Ş. (2009). SPSS Uygulamalı Çok Değişkenli İstatistik Teknikleri, 4. Baskı, Asil Yayın Dağıtım Ltd. Şti. Ankara.

Kennelly, B., O’Shea, E., \& Garvey, E. (2003). Social capital, life expectancy and mortality: a cross-national examination. Social Science \& Medicine, 56(12), 2367-2377. http://dx.doi.org/10.1016/S0277-9536(02)00241-1

Marmot, M.G., \& Smith, G.D. (1989). Why are the Japanese living longer? British Medical Journal (BMJ), 299(6715), 1547-51.

Mayrhofer, T., \& Schmitz, H. (2014). Testing the relationship between income inequality and life expectancy: a simple correction for the aggregation effect when using aggregated data. Journal of Population Economics, 27(3), 841-856. http://dx.doi.org/10.1007/s00148-013-0483-7

Mcdonough, P., Duncan, G.J., Williams, D., \& House, J. (1997). Income dynamics and adult mortality in the United States, 1972 through 1989. American Journal of Public Health, 87(9), 1476-83. http://dx.doi.org/10.2105/AJPH.87.9.1476

OECD. (2011). Health at a Glance 2011: OECD Indicators. OECD Publishing. http://dx.doi.org/10.1787/health_glance-2011-en

Palme, M., \& Sandgren, S. (2008). Parental Income, Lifetime Income and Mortality. Journal of the European Economic Association, 6(4), 890-911. http://dx.doi.org/10.1162/JEEA.2008.6.4.890

Rodgers, G.B. (2002). Income and inequality as determinants of mortality: an international cross-section analysis. International Journal of Epidemiology, 31(3), 533-538. http://dx.doi.org/10.1093/ije/31.3.533

Sen, A. (2004). Özgürlükle Kalkınma (Development as Freedom), (Çeviren:Yavuz Alogan), Ayrıntı Yayınları, İstanbul.

Tacke, T., \& Waldmann, R. J. (2013). Infant mortality, relative income and public policy. Applied Economics, 45(22), 3240-3254. http://dx.doi.org/10.1080/00036846.2012.705429

The Sustainable Development Solutions Network (SDSN). (2014). Health in the Framework of Sustainable Development,Technical Report for the Post-2015 Development Agenda, Prepared by the Thematic Group on Health for All of the Sustainable Development Solutions Network, (18 February 2014). Retrieved April 10, 2015, from http://unsdsn.org/wp-content/uploads/2014/02/Health-For-All-Report.pdf

UNDP. (2014a). Human Development Report Technical Notes 2014. Retrieved April 10, 2015, from http://hdr.undp.org/sites/default/files/hdr14_technical_notes.pdf

UNDP (2014b). FAQ Inequality-adjusted Human Development Index. Yeni Ufuklar Dergisi, Sayı: Özel Sayı/Eylül 2014, Retrieved April 9, from http://www.tr.undp.org/content/dam/turkey/docs/Publications/hdr/HDR2014\%20FAQ\%20IHDI\%20EN.pdf 
UNDP (2014c). Human Development Report 2014, Sustaining Human Progress: Reducing Vulnerabilities and Building Resilience. $\quad$ Retrieved April 10, 2015, from http://hdr.undp.org/en/content/human-development-report-2014

UNDP (2014d). Human Development Report Statistical Tables 2014. Retrieved August 16, 2016, from http:/hdr.undp.org/en/content/human-development-report-2014

\section{Notes}

Note 1. SDSN refers to The Sustainable Development Solutions Network in this study.

Note 2. In UNDP's 2014 Human Development Report, the world average of gross national income per capita for the year 2013 is $\$ 13.723$.

\section{Annex}

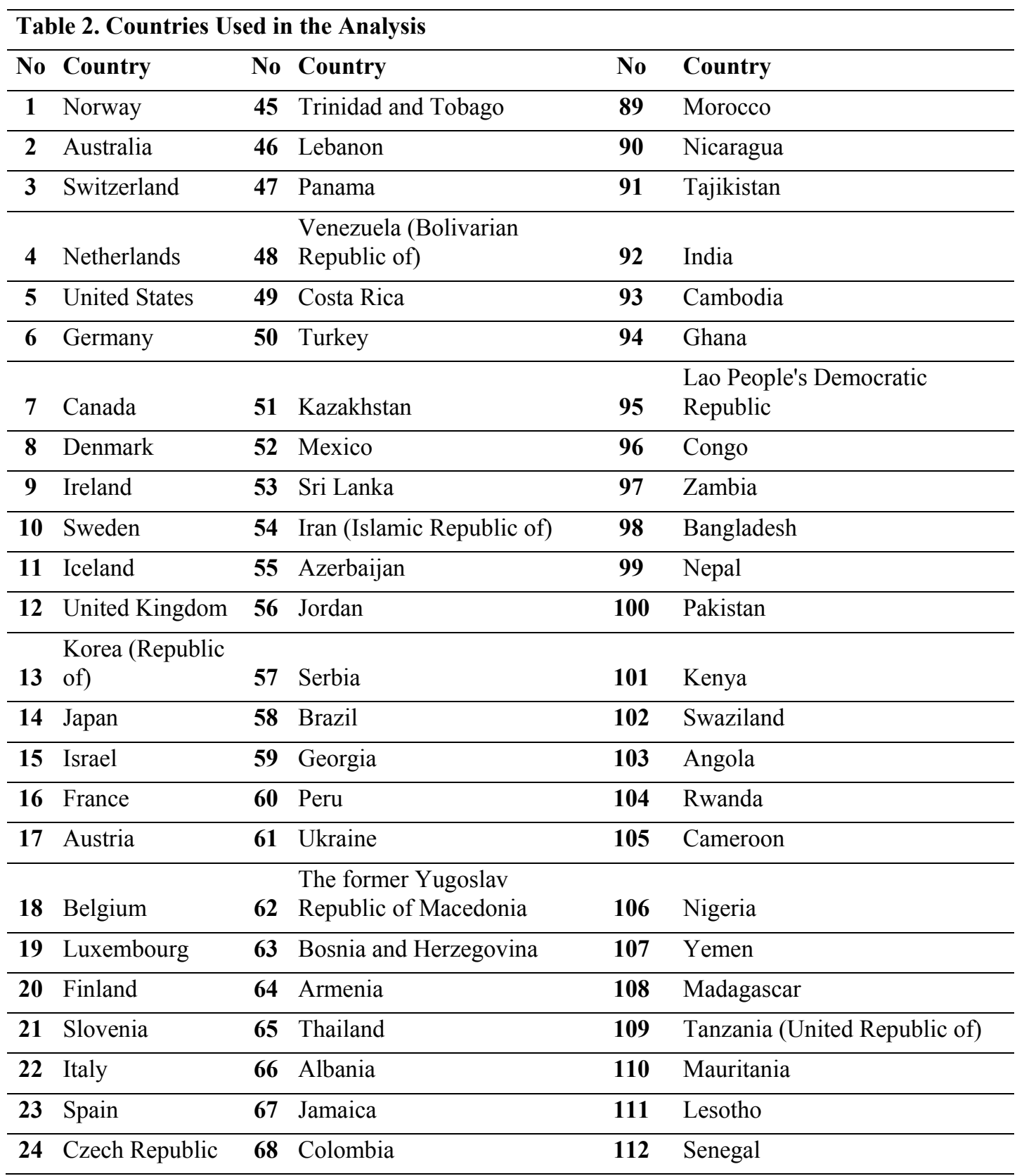




\begin{tabular}{|c|c|c|c|c|c|}
\hline 25 & Greece & 69 & Ecuador & 113 & Uganda \\
\hline 26 & Cyprus & 70 & Suriname & 114 & Benin \\
\hline 27 & Estonia & 71 & Dominican Republic & 115 & Togo \\
\hline 28 & Lithuania & 72 & Mongolia & 116 & Haiti \\
\hline 29 & Poland & 73 & Indonesia & 117 & Afghanistan \\
\hline 30 & Slovakia & 74 & Botswana & 118 & Djibouti \\
\hline 31 & Malta & 75 & Egypt & 119 & Côte d'Ivoire \\
\hline 32 & Chile & 76 & Paraguay & 120 & Malawi \\
\hline 33 & Portugal & 77 & Gabon & 121 & Liberia \\
\hline 34 & Hungary & 78 & $\begin{array}{l}\text { Bolivia (Plurinational State } \\
\text { of) }\end{array}$ & 122 & Mozambique \\
\hline 35 & Croatia & 79 & Moldova (Republic of) & 123 & Guinea \\
\hline 36 & Latvia & 80 & El Salvador & 124 & Burundi \\
\hline 37 & Argentina & 81 & Uzbekistan & 125 & Burkina Faso \\
\hline 38 & Uruguay & 82 & Philippines & 126 & Sierra Leone \\
\hline 39 & Montenegro & 83 & Syrian Arab Republic & 127 & Chad \\
\hline 40 & Belarus & 84 & Iraq & 128 & Central African Republic \\
\hline 41 & Romania & 85 & Viet Nam & 129 & $\begin{array}{l}\text { Congo (Democratic Republic of } \\
\text { the) }\end{array}$ \\
\hline 42 & $\begin{array}{l}\text { Russian } \\
\text { Federation }\end{array}$ & 86 & Guatemala & 130 & Niger \\
\hline 43 & Bulgaria & 87 & Kyrgyzstan & & \\
\hline 44 & Mauritius & 88 & Honduras & & \\
\hline
\end{tabular}

